AC 2007-1047: A COMPREHENSIVE EXAMINATION OF THE IMPACT OF THE SUMMER UNDERGRADUATE RESEARCH PROGRAM ON MINORITY

ENROLLMENT IN GRADUATE SCHOOL

JillL Auerbach, Georgia Institute of Technology

Jonathan Gordon, Georgia Institute of Technology

Gary May, Georgia Institute of Technology

Cleon Davis, Georgia Institute of Technology 


\title{
A Comprehensive Examination of the Impact of the Summer Undergraduate Research Program on Minority Enrollment in Graduate School
}

\begin{abstract}
A widespread strategy to encourage minority students to attend graduate school in science, technology, engineering, and mathematics (STEM) fields is to engage students in undergraduate research. The Summer Undergraduate Research in Engineering/Science (SURE) program at [INSTITUTION]--a highly selective technology-focused research institution--was first implemented in 1992. SURE is a ten-week summer program for junior- and senior-level minority undergraduates from a variety of institutions. Students paired with faculty and graduate mentors on research projects attend enrichment activities and conclude the program with research presentations to their peers and program faculty. In 2005, a survey of former SURE participants was conducted. Of the 62 respondents who had completed their bachelors' degrees, 72.6 percent indicated they had enrolled in or completed a graduate program of study. In addition to the positive impact the SURE experience had on the decision to attend graduate school (93.5 percent of respondents), this research uses logistic regression techniques to illuminate other relevant factors on graduate school attendance--such as attitudes about graduate school before SURE, the environment of the home institution, academic encouragement from others, and frequency of contact with SURE faculty and mentors after program completion.
\end{abstract}

\section{Introduction}

Despite some gains in the representation of minorities in engineering and science fields, a relatively small number of underrepresented minorities (16\% in 1999) graduated with degrees in those fields. ${ }^{1}$ Although this figure represents a modest increase over the previous decade, minority representation drops significantly for advanced engineering degrees, and only $11.5 \%$ of Master's and $8.7 \%$ of the Ph.D. degrees awarded in that same year were earned by these students. This underrepresentation has led to a proportionally small percentage of tenure-track minority science and engineering faculty (6.8\%). The encouraging upward trend in undergraduate education among minorities in the STEM fields is somewhat tempered by more recent data issued by NSF. According to a 2004 report on the proportion of minority students enrolled in undergraduate engineering programs, enrollment increased steadily from 1990-1998. The trend changed in the late 1990s when minority enrollment actually decreased. ${ }^{1}$ This decline in undergraduate enrollment could have a negative impact on graduate degrees earned by minority students in engineering.

The decline in undergraduate enrollment in engineering among minorities was noted by Asa ${ }^{2}$ who provided a comprehensive examination of minority education trends. This decline has occurred despite efforts by institutions to attract and retain minority students in engineering. In the STEM fields overall, earned bachelor's among minority populations rose throughout the 1990s and narrowed the gap between white and non-white degree holders. ${ }^{1}$ At the master's degree level, the number of degrees earned among these populations also increased. 
One of the innovative strategies to encourage students to attend graduate school in STEM fields is to engage students in undergraduate research. To support this effort, the National Science Foundation sponsors the Research Experience for Undergraduates (REU) program at numerous colleges and universities around the country to expand student participation in a broad range of research areas. The breadth of undergraduate research opportunities (UROs) is borne out in a broadly focused 2003 National Science Foundation (NSF) sponsored study that inventories over 1,000 NSF undergraduate research awards. ${ }^{3}$

Fruitful research experiences as an undergraduate can be effective in helping students who exhibit uncertainty or lack of confidence about graduate school attendance. According to a recent study by SRI International, ${ }^{4}$ undergraduate research programs can assist students who are uncertain about going to graduate school to clarify their intent to pursue those goals and to reinforce the commitment among students who have already decided to pursue those goals. The decision to attend graduate school can be highly influenced by the amount of faculty involvement in the undergraduate career of minority students. ${ }^{5}$ Quality interactions with faculty can have a significant impact on a student's decision to pursue graduate education, since such interaction provides the student with effective role models. Thus, faculty members in science and engineering fields are a critical link in the challenge to increase the likelihood that minority students will attend graduate school.

A study of graduate engineering education of underrepresented populations by Reichert and Absher measured the persistence of various population segments in progressing from undergraduate to graduate programs. 6 The results of this study indicated the persistence gap between majority students and underrepresented minorities is evident only when proceeding from either the B.S. or M.S. to the Ph.D., which implies that once admitted to graduate school, underrepresented students are equally committed to pursing the doctorate. The primary challenge, therefore, is getting underrepresented students to consider, and select, the graduate school option. Undergraduate research programs are an essential component of enhancing minority enrollment in advanced degree programs and ultimately, increasing the size of the minority Ph.D. population. ${ }^{7,8}$

\section{Program Description}

The Summer Undergraduate Research in Engineering/Science (SURE) program was first implemented in 1992 at the [INSTITUTION]. SURE is conducted in conjunction with the Colleges of Engineering, Sciences, and Computing, as well as the NSF-sponsored Engineering Research Center (ERC) in Low-Cost Electronics Packaging. It is a ten-week program open to junior- and senior-level undergraduate students from across the nation that exposes minority students to engineering research with the intent of increasing the number of minority students who attend graduate school. SURE students are selected from a competitive pool of applicants by a committee of faculty research advisors who consider students' academic records, faculty letters of recommendation, and student skills and interests.

SURE students receive subsidized on-campus housing for the duration of the program, a meal plan, travel allowance, and full access to institutional facilities, including health care, recreational facilities, and the library. In addition, the participants are awarded a stipend. The financial incentives offered by SURE are designed to attract some of the best available students, 
many of whom choose to participate instead of accepting more lucrative summer employment offers in industry. In addition to their research projects, students participate in a series of seminars and field trips to expose them to the graduate application process, funding for graduate school, and cutting-edge research being performed at the university and in surrounding industrial research centers. At the conclusion of the program, the students present both oral and written projects to faculty advisors and graduate student mentors.

Since the SURE program inception, the number of applications has dramatically increased while growth in the number of supported undergraduate research positions in the program has been capped due to institutional, financial, and practical constraints. In Table 1, the number of SURE program applications and acceptances over five years is shown.

Table 1 -- Number of SURE applications and acceptances from 1999-2003

\begin{tabular}{|l|c|c|c|}
\hline Year & Applied & Selected & \% \\
\hline 1999 & 91 & 18 & 19.8 \\
\hline 2000 & 111 & 27 & 24.3 \\
\hline 2001 & 104 & 23 & 22.1 \\
\hline 2002 & 165 & 27 & 16.3 \\
\hline 2003 & 155 & 26 & 16.7 \\
\hline
\end{tabular}

To facilitate interaction between the minority student participants and [INSTITUTION] faculty members, each SURE student is paired with a faculty member who serves as the research advisor. These direct one-on-one relationships are meant to enhance the research experience of the undergraduates by providing practical examples of the typical day-to-day interactions that take place between professors and graduate students. ${ }^{9}$ In addition to faculty advisors, SURE students are also assigned graduate student mentors. Pairing undergraduate students with graduate students closer to their peer group is intended to ease student communication and help alleviate any discomfort, which the undergraduates might feel as they acclimate themselves to the research environment.

\section{Longitudinal Survey of Former SURE Participants from 1999-2003}

Because limited resources are available to develop successful strategies for increasing minority enrollment in STEM graduate programs, extant programs must be continually assessed to determine the more efficient programs. A variety of methods is used in conjunction with the SURE program and include surveys of participants, both before and after their research experiences, and mid-program focus group sessions. Additionally, long-term follow up of SURE participants is employed for assessing the impact of the program.

Longitudinal studies present special challenges. Locating former program participants is difficult due to outdated contact information. Another challenge is that subjects may not accurately recall the events that took place several years back, so results need to be interpreted carefully.

The study was conducted in 2005 on the population of students who were participants in the 1999-2003 SURE programs. Thus, respondents had been out of the SURE program for at least 
two years. Most participants were rising-junior or seniors at the time of the program, so two years was a reasonable interlude to provide students time to complete their baccalaureate studies and enter a graduate program.

A SURE participant alumni list with contact information was maintained for the selected years, but had limited accuracy. The survey was conducted electronically (via the Internet). Carefully following the Dillman ${ }^{10}$ Internet survey method to maximize response rate, an initial email message was sent to respondents from the SURE program director to alert them that an electronic survey would arrive within the week. This first email served two purposes: to alert respondents about the survey with a short email message from a familiar sender and to determine how many email messages would bounce back. In the case of email addresses that bounced, various attempts to update contact information were made. These attempts consisted of electronic searches and phone calls to locate the participant. Ultimately, this contributed to a 58.7 percent response rate from the population of all former SURE participants from 1999-2003. A total of 71 responses were obtained, of which 62 had completed their baccalaureate programs of study. It is this latter number upon which our analysis proceeded.

Respondents were asked a variety of questions about their academic decisions after participating in the SURE program. Detailed data about graduate school attendance, degree attainment, and major was collected. Questions were included to obtain feedback about their co-curricular activities and the environment of their undergraduate institutions. Another set of questions referred to sources of encouragement that students may have had when deciding to attend graduate school. Finally, a series of questions that asked about specific experiences during SURE were included.

\section{Research Questions}

The foundation of this research was to determine if SURE participants subsequently chose to attend graduate programs of study and what factors may be associated with this decision. Specifically, our research questions were as follows:

- Do co-curricular activities at the students' home institutions-such as membership in professional organizations, co-op participation, or other undergraduate research activities - play a role in graduate school attendance?

- What are the influences of students' peers and family on the decision to attend graduate school?

- What role did the SURE program in general play in the decision to attend graduate school?

- What effect does the mentoring provided by the SURE program have on the decision to attend graduate school?

Thus, this research examines the educational context before SURE participation, opinions about the SURE experience, post-program contact with SURE mentors, and the long term academic decisions of the former participants. Not only does this research extend our understanding of the varying benefits of summer research programs, but it identifies important elements other than program components that impact graduate school decisions. 


\section{Data Analysis}

The results are presented in several ways. First, some basic descriptive information regarding the respondents is provided. Second, crosstabulations of responses and chi-square analyses are presented based on whether or not the SURE participant chose to attend graduate school. Finally, a logistic regression is presented on two sets of variables - those representing the co-curricular activities of the students and those representing the SURE experiences and peer/family influences on the respondents regarding graduate school.

Basic demographic information about the respondents is presented in Table 2. As shown in Table 2, a substantial number of respondents (72.6 percent) enrolled in or completed a graduate program of study. 
Table 2 -- Respondents Demographic Data

\begin{tabular}{|l|c|}
\hline & $\begin{array}{c}\text { Percent of Respondents } \\
\text { (N=62) }\end{array}$ \\
\hline Male & 51.6 \\
\hline Female & 48.4 \\
\hline Enrolled in Graduate School & 72.6 \\
\hline $\begin{array}{l}\text { Type of Undergraduate } \\
\text { Institution }\end{array}$ \\
\hline HBCU \\
\hline Research/Doctoral & 45.2 \\
\hline Master's & 56.0 \\
\hline Baccalaureate & 17.0 \\
\hline Dual Degree Program & 14.0 \\
\hline Year Attended SURE & 13.0 \\
\hline 1999 & \\
\hline 2000 & 6.5 \\
\hline 2001 & 24.2 \\
\hline 2002 & 21.0 \\
\hline 2003 & 32.3 \\
\hline Undergraduate Major & 16.1 \\
\hline Science & \\
\hline Engineering & 29.0 \\
\hline $\begin{array}{l}\text { Number of Undergraduate } \\
\text { Institutions Attended }\end{array}$ & 71.0 \\
\hline One & \\
\hline Two & 72.6 \\
\hline Three & 24.2 \\
\hline Graduate School Status & 3.2 \\
\hline Completed Masters Degree & 14.5 \\
\hline $\begin{array}{l}\text { Currently Enrolled in } \\
\text { Masters Program }\end{array}$ & 17.7 \\
\hline $\begin{array}{l}\text { Currently Enrolled in PhD } \\
\text { Program }\end{array}$ & 33.9 \\
\hline $\begin{array}{l}\text { Enrolled, But Did Not } \\
\text { Complete Masters Program }\end{array}$ & 6.5 \\
\hline $\begin{array}{l}\text { Did Not Enroll in Any } \\
\text { Graduate Program }\end{array}$ & \\
\hline & \\
\hline & \\
\hline
\end{tabular}

SURE alumni were asked if they had participated in a variety of co-curricular activities. A crosstabulation was conducted based on whether or not the respondent chose to attend graduate school. The results are presented in Table 3. 
Table 3 -- Undergraduate Co-Curricular Activities: Percent of Respondents by Graduate School Attendance/Non-Attendance Who Indicated Participation in Each Activity

\begin{tabular}{|l|c|c|c|}
\hline $\begin{array}{l}\text { Undergraduate } \\
\text { Membership/Activity }\end{array}$ & $\begin{array}{c}\text { Attended } \\
\text { Graduate School } \\
\text { (n=45) }\end{array}$ & $\begin{array}{c}\text { Did Not Attend } \\
\text { Graduate School } \\
\text { (n=17) }\end{array}$ & Total \\
\hline Honor Society & 62.2 & 47.1 & 58.1 \\
\hline $\begin{array}{l}\text { Professional Society (e.g. } \\
\text { ASME, IEEE Student Branch) }\end{array}$ & 28.9 & 29.4 & 29.0 \\
\hline $\begin{array}{l}\text { National Society of Black } \\
\text { Engineers }\end{array}$ & 68.9 & 70.6 & 69.4 \\
\hline Fraternity/Sorority & 26.7 & 11.8 & 22.6 \\
\hline Student Government & 22.2 & 17.6 & 21.0 \\
\hline Campus Athletics & 20.0 & 11.8 & 32.3 \\
\hline $\begin{array}{l}\text { College Sponsored } \\
\text { Community Service } \\
\text { Organizations }\end{array}$ & 26.7 & 47.1 & 21.0 \\
\hline Campus Ministry & & & 58.1 \\
\hline $\begin{array}{l}\text { Employed on a research } \\
\text { project }\end{array}$ & 20.0 & 23.5 & 37.1 \\
\hline $\begin{array}{l}\text { Course-credit for Research } \\
\text { Project }\end{array}$ & 62.2 & 47.1 & 69.4 \\
\hline Research-oriented Internship & 35.6 & 41.2 & 24.2 \\
\hline Industry Co-op & 26.7 & 58.8 & 14.5 \\
\hline Study Abroad & 15.6 & 17.6 & \\
\hline
\end{tabular}

Some differences in the co-curricular activities of graduate school attendees and non-attendees can be noted, but a distinct pattern is not discernable. Since undergraduate research experience is generally viewed as having some academic benefit, two co-curricular activities are particularly relevant to this research. Of those respondents who attended graduate school, $62.2 \%$ were employed on a research project at their home institution compared to $47.1 \%$ of non-attendees. In addition, $41.2 \%$ of non-attendees reported earning course credit for research and $58.8 \%$ had research-oriented internships. Comparatively, only 35.6\% of students who did attend graduate school had earned course credit for research at the undergraduate level. Based upon this data, a substantial portion of students who did not attend graduate school reported having undergraduate research experiences. On several other activities, differences between the two groups are more evident, but the chi-square analysis does not reveal any of these to be significant at the $\mathrm{p}<.05$ level.

In Table 4, responses to a variety of questions about sources of support or influence for graduate school attendance are presented. A comparison of the frequency distributions for each cohort of SURE alumni shows several similarities between the two groups on these measures. In contrast, on items about encouragement from others to attend graduate school, differences begin to emerge. Students who attended graduate school tended to report more frequent encouragement from family and friends. One of these items showed a significant difference between the 
graduate school attendees and non-attendees: encouragement from the students' families. Almost three-quarters of those who attended graduate school reported encouragement from their family members helped in their decision, while less than half of those who did not attend reported similar encouragement.

It would appear that regardless of whether or not the respondent eventually attended graduate school, participants agreed that the SURE experience was beneficial to their careers-93.3 percent of graduate school attendees, and 88.2 percent of non-attendees agreed with this statement.

Table 4 -- Influential Factors on Graduate School Attendance: Percent Responding “Agree” or "Strongly Agree”

\begin{tabular}{|l|c|c|c|}
\hline Item & $\begin{array}{c}\text { Attended Graduate } \\
\text { School } \\
\text { (n=45) }\end{array}$ & $\begin{array}{c}\text { Did Not Attend } \\
\text { Graduate School } \\
\text { (n=17) }\end{array}$ & $\begin{array}{c}\text { Total } \\
\text { (n=62) }\end{array}$ \\
\hline $\begin{array}{l}\text { There were several/ample } \\
\text { opportunities for } \\
\text { undergraduate research at my } \\
\text { home institution }\end{array}$ & 75.6 & 76.5 & 75.8 \\
\hline $\begin{array}{l}\text { Faculty in my undergraduate } \\
\text { program encouraged me to } \\
\text { attend graduate school }\end{array}$ & 77.8 & 64.7 & 74.2 \\
\hline $\begin{array}{l}\text { My family encouraged me to } \\
\text { attend graduate school* }\end{array}$ & 73.3 & 47.1 & 66.1 \\
\hline $\begin{array}{l}\text { Friends from undergraduate } \\
\text { school encouraged me to } \\
\text { attend graduate school }\end{array}$ & 77.8 & 58.8 & 72.6 \\
\hline $\begin{array}{l}\text { Many of my current friends } \\
\text { have attended graduate school }\end{array}$ & 62.2 & 52.9 & 82.3 \\
\hline $\begin{array}{l}\text { Before participating in SURE, } \\
\text { I strongly considered graduate } \\
\text { school }\end{array}$ & 86.7 & 70.6 & \\
\hline $\begin{array}{l}\text { After participating in SURE, I } \\
\text { strongly considered graduate } \\
\text { school }\end{array}$ & 95.6 & 88.2 & 93.5 \\
\hline $\begin{array}{l}\text { Overall, my experience with } \\
\text { SURE was beneficial to my } \\
\text { future career }\end{array}$ & 93.3 & & \\
\hline F & & & \\
\hline
\end{tabular}

*Chi-square $\mathrm{p}=<.05$

Another interesting finding is the influence of the SURE program on participants' consideration of graduate school. Using a four-point Likert scale (4=strongly agree; 1 =strongly disagree), a matched-pairs analysis, respondents indicated that their interest in graduate school had increased. The results are presented in the Table 5. For all respondents who enrolled in graduate school 
$(\mathrm{n}=62)$, the mean agreement score increased by 0.21 . Put another way, while 82.3 percent of respondents agreed that they were interested in attending graduate school before their SURE experience, 93.5 percent were interested after the experience.

Table 5 --Mean Agreement Score for All SURE Respondents

\begin{tabular}{|l|c|c|c|}
\hline & $\begin{array}{c}\text { Before } \\
\text { participating in } \\
\text { SURE, I strongly } \\
\text { considered } \\
\text { graduate school }\end{array}$ & $\begin{array}{c}\text { After participating } \\
\text { in SURE, I } \\
\text { strongly } \\
\text { considered } \\
\text { graduate school }\end{array}$ & Difference \\
\hline Mean Response & 3.27 & 3.48 & $0.21^{*}$ \\
\hline Standard Error & .09 & .10 & \\
\hline
\end{tabular}

*t test $\mathrm{p}<.05$

As can be seen in Table 6, participants who eventually attended graduate school tended to report similar types of experiences with the SURE program, such as discussing graduate school with others. However, graduate school attendees were more likely to report discussing graduate school possibilities with their SURE peers. Graduate school attendees were also more likely to report discussing research possibilities with their faculty mentors as well (33.3 percent versus 11.8 percent). A chi-square test of this finding approached statistical significance at $\mathrm{p}=.09$ ). 
Table 6 -- Influential Factors on Graduate School Attendance: Percent Responding "Frequently" or "Fair Amount"

\begin{tabular}{|l|c|c|c|}
\hline & $\begin{array}{c}\text { Attended Graduate } \\
\text { School } \\
\text { (n=45) }\end{array}$ & $\begin{array}{c}\text { Did Not Attend } \\
\text { Graduate School } \\
\text { (n=17) }\end{array}$ & $\begin{array}{c}\text { Total } \\
\text { (n=62) }\end{array}$ \\
\hline $\begin{array}{l}\text { Discuss graduate } \\
\text { school with SURE } \\
\text { program mentor }\end{array}$ & 55.6 & 47.1 & 53.2 \\
\hline $\begin{array}{l}\text { Discuss graduate } \\
\text { school with SURE } \\
\text { program faculty } \\
\text { advisor }\end{array}$ & 51.1 & 35.3 & 46.8 \\
\hline $\begin{array}{l}\text { Discuss graduate } \\
\text { school with other }\end{array}$ & 86.7 & 52.9 & 77.4 \\
$\begin{array}{l}\text { SURE program } \\
\text { participants* }\end{array}$ & & & \\
\hline $\begin{array}{l}\text { Discuss graduate } \\
\text { school with other } \\
\text { SURE program or } \\
\text { university staff }\end{array}$ & 46.7 & 47.1 & 46.8 \\
\hline $\begin{array}{l}\text { Discuss with SURE } \\
\text { program mentor } \\
\text { research ideas for } \\
\text { graduate school }\end{array}$ & 24.4 & 23.5 & \\
\hline $\begin{array}{l}\text { Discuss with SURE } \\
\text { program faculty } \\
\text { advisor research } \\
\text { ideas for graduate } \\
\text { school }\end{array}$ & 33.3 & & 24.2 \\
\hline $\begin{array}{l}\text { Discuss with other } \\
\text { SURE program } \\
\text { participants research } \\
\text { ideas for graduate } \\
\text { school }\end{array}$ & & & \\
\hline & & & \\
\hline Chi-saure p & & & \\
\hline
\end{tabular}

${ }^{*}$ Chi-square $\mathrm{p}=<.05$

When asked about follow-up contacts with their graduate and faculty mentors after their SURE experiences, responses differed significantly. SURE participants who attended graduate school were much more likely to have maintained a relationship with their mentors after the program had ended. The results are presented in Table 7. 
Table 7 -- Post-SURE Contact with Mentors and Advisors

\begin{tabular}{|l|c|c|c|}
\hline & $\begin{array}{c}\text { Attended Graduate } \\
\text { School } \\
\text { (n=45) }\end{array}$ & $\begin{array}{c}\text { Did Not Attend } \\
\text { Graduate School } \\
\text { (n=17) }\end{array}$ & $\begin{array}{c}\text { Total } \\
\text { (n=62) }\end{array}$ \\
\hline $\begin{array}{l}\text { More than two } \\
\text { follow-up contacts } \\
\text { with SURE graduate } \\
\text { mentor* }\end{array}$ & 51.1 & 17.6 & 41.9 \\
\hline $\begin{array}{l}\text { More than two } \\
\text { follow-up contacts } \\
\text { with SURE faculty } \\
\text { advisor* }\end{array}$ & 57.8 & 29.4 & 50.0 \\
\hline
\end{tabular}

*Chi-square $\mathrm{p}=<.05$

Of those who subsequently enrolled in graduate school, 51.1 percent reported having at least three contacts (either through email, phone, or face-to-face meetings) with their graduate mentors, and 57.8 percent reported a similar number of contacts with their SURE faculty advisors. For those who did not attend graduate school, the comparable numbers are 17.6 percent and 29.4 percent, respectively.

\section{Logistic Regression}

To further explore what factors were related to a SURE participant's decision to attend graduate school, we employed logistic regression analysis. Logistic regression is often used in evaluating a dichotomous outcome variable, such as graduate school attendance. Because we did not have an a priori theory to explain SURE participant behavior, we utilized a forward stepwise regression approach. That is, independent variables were entered into the model one at a timethose with suitable explanatory power were retained in the model, while those without were rejected. Fitting the model to the data in this way may introduce noise into the equations and can limit the generalizability of the results; however, this approach is appropriate in data exploration. $^{11}$

The independent variables were entered in two blocks. The first block contained variables relating to the participants' undergraduate experiences. These included co-curricular activities (for example, fraternity/sorority membership, co-op participation, and other undergraduate research experiences). Also included was membership in professional and honor societies (e.g. National Society of Black Engineers, Eta Kappa Nu, ASME, and IEEE Student Branch). The students' gender and whether or not they attended a Historically Black College or University (HBCU) were also included in this block. The second block consisted of variables relating to the students' SURE experience. These variables included participants' opinions about the impact of SURE on their educational development, faculty, peer and family influences on their decision about graduate school and the frequency of contact with their SURE program mentors and faculty advisors. Responses to these items were on a four-point Likert scale (either "Strongly Agree” to "Strongly Disagree," or "Frequently" to "Not at All," depending on the question). The regression model is presented below. 
Table 8 -- Logistic Regression Analysis of 62 SURE Participants on Their Decision to Attend Graduate School (Two Step Forward Likelihood Ratio Method)

\begin{tabular}{|l|c|c|c|c|c|c|}
\hline Predictor & $\boldsymbol{\beta}$ & $\begin{array}{c}\text { Std. } \\
\text { Error } \boldsymbol{\beta}\end{array}$ & Wald $\chi^{2}$ & d.f. & $\boldsymbol{p}$ & $\begin{array}{c}\text { Odds } \\
\text { Ratio } \\
\left(\mathrm{e}^{\boldsymbol{\beta}}\right)\end{array}$ \\
\hline Constant & -5.716 & 2.147 & 7.088 & 1 & .008 & N/A \\
\hline $\begin{array}{l}\text { Family } \\
\text { Encouragement }\end{array}$ & .954 & .406 & 5.527 & 1 & .019 & 2.595 \\
\hline $\begin{array}{l}\text { Discussion } \\
\text { with SURE } \\
\text { Participants }\end{array}$ & 1.479 & .522 & 8.020 & 1 & .005 & 4.388 \\
\hline $\begin{array}{l}\text { Discussion } \\
\text { with } \\
\text { SURE/Other } \\
\text { Staff }\end{array}$ & -.858 & .452 & 3.601 & 1 & .058 & .424 \\
\hline $\begin{array}{l}\text { Post-SURE } \\
\text { Faculty } \\
\text { Advisor } \\
\text { Contacts }\end{array}$ & .638 & .291 & 4.808 & 1 & .028 & 1.893 \\
\hline
\end{tabular}

\begin{tabular}{|l|c|c|c|c|}
\hline Test & $\chi^{2}$ & d.f. & $\boldsymbol{p}$ & $\boldsymbol{R}^{2}$ \\
\hline Overall model evaluation & & & & \\
\hline Likelihood Ratio Test & 18.072 & 4 & .001 & \\
\hline Goodness of Fit Test & & & & \\
\hline Hosmer \& Lemeshow & 4.303 & 8 & .829 & \\
\hline Cox \& Snell $R^{2}$ & & & & .253 \\
\hline Nagelkerke $R^{2}$ & & & & .366 \\
\hline
\end{tabular}

A test of the stepwise generated model over a model containing just the intercept (constant) was significant $\left(\chi^{2}=18.072\right.$, d.f. $\left.=4, \mathrm{p}=.001\right)$, and using a 0.5 cutoff, the model was able to correctly classify 93.3 percent of the graduate school occurrences and 58.8 percent of the non-graduate school occurrences for an overall success rate of 83.9 percent. None of the variables entered in the first block were retained in the model using a forward stepwise method. In the second block, four variables were retained in the model. Three of these variables had statistically significant partial effects on graduate school attendance. The odds ratio for family encouragement indicates that-holding all other variables constant-for each one point increase on the Likert scale of agreement on this item, the odds that the SURE participant attended graduate school increased by a factor of 2.60. Put another way, SURE participants who discussed graduate school possibilities with their SURE peers were more likely to attend graduate school as well. For each one point increase on the likert scale of frequency on this item, the odds that the SURE participant chose to attend graduate school increased by a factor of 4.39. The most interesting result is that continued contact with a student's SURE faculty advisor increased the likelihood of attending graduate school. For each unit increase in frequency of post-SURE contact, the odds of 
that student attending graduate school improved by a factor of 1.89. Put another way, students who had frequent (i.e. three to six) contacts with their SURE faculty advisors were 189 percent more likely to attend graduate school than one who had only occasional (i.e. once or twice) contact with their advisor. There is one anomalous finding from the model. The amount of discussion a SURE participant had with other SURE program staff was inversely related to the odds of their attending graduate school. Using an inverted odds ratio, each unit increase in frequency of these discussions by SURE participants reduced the odds of graduate school attendance by a factor of 2.36 . However, the effect of this variable did not quite rise to the 05 level of statistical significance.

\section{Discussion}

This analysis clearly shows that the two groups_-SURE graduate school attendees and nonattendees-were very similar on many indicators. The most obvious commonality is that all are students who sought out and accepted enrollment in the SURE program. In the analysis of preand post-SURE attitudes about graduate school attendance, high proportions of both cohorts of students said that they were strongly considering graduate school both before and after SURE. In fact, the percentage increase of those strongly considering graduate school before and after SURE was larger among the non-attendees. This self-reported attitude data appears limiting to distinguish the two cohorts, but is encouraging since SURE had an impact on almost all students to at least consider graduate school. Another important aspect of the impact of SURE was that almost all students felt that the experience was beneficial to their careers. This suggests that even though the main objective of programs like SURE is to increase minority graduate school enrollment, students find the experience helpful to their future careers regardless of whether they attend graduate school.

In terms of activities at the home institutions of participants, little variation was revealed by the data. Both groups reported high levels of participation in research activities and low levels of industry co-op positions. This analysis revealed that these variables did not play a role in graduate school attendance and there were not significant differences between the two groups on these variables.

An unexpected finding from this study is the impact of family encouragement on the decision to attend graduate school. The influence of family stands out among numerous variables such as undergraduate research experiences at the home institutions, faculty encouragement to attend graduate school, peer influences, and discussions about graduate school with SURE mentors and faculty advisors. Even though all SURE students were already in undergraduate school, encouragement from family increased the likelihood that students would attend graduate school.

The impact of peers presents an interesting finding as well. Students who attended graduate school were no more likely to have friends that attended graduate school or to have received encouragement from friends in undergraduate school than the non-attendee students, but graduate school attendees were more likely to discuss graduate school with other SURE participants. This may indicate that being with other students who were inclined towards graduate school attendance was reinforced among this group of students and had a lasting impact on their decision. 
Since students who attend summer undergraduate research experiences typically have at least two semesters of undergraduate school remaining, the lasting impact of programs like SURE could be mitigated by the gap between the program and undergraduate degree completion. Ongoing contact with SURE mentors and/or faculty research advisors may help fill this potential gap. According to this analysis, extended contact with both the mentors and research faculty differed significantly between the two student cohorts. In fact, this analysis shows that more frequent interaction translates to increased likelihood of attending graduate school

Even though this survey was conducted at least two years after participating in SURE, some of the students who did not attend graduate school at the time the survey was administered could attend at a later time. In order to track SURE students as accurately as possible, the nonattendees should be contacted again and appropriate adjustments to the data must be made.

One of the limitations of this analysis is that both student cohorts were SURE program participants. The next step in this research process will include a third student cohort that did not participate in any undergraduate summer research programs. This will provide a comparison group of students who utilized their time in the summer differently than these students. Industry internships, taking classes, working, or even spending summer months leisurely are choices of many undergraduate students. Comparisons among students with and without concentrated summer research experiences will enhance our understanding of the impact of these programs to increase the number of minority students who attend graduate school in science and engineering.

The implications of this research are twofold. First, these findings reveal that family encouragement is a major factor in the decision to attend graduate school. While family encouragement may be important to most students, it is a critical element to the minority students who participated in the SURE program. Second, certain SURE program characteristics that are typical of many summer undergraduate research experiences had a positive impact on the decision to attend graduate school. Continued contact with mentors and research faculty is highly associated with graduate school attendance. Thus, maintaining relationships that were established in the research environment was highly effective towards realizing the overall objective of the program.

\section{References}

1 "Women, Minorities, and Persons with Disabilities in Science and Engineering: 2002," National Science Foundation 2002.

2 E. Asa, "Engineering Education of Minorities: An Overview," presented at Proceedings of the 2006 American Society for Engineering Education Annual Conference \& Exposition, 2006.

3 C. Ailes, M. Hancock, J. McCullough, J. D. Roessner, and C. Storey, "Evaluation of NSF Support for Undergraduate Research Opportunities 2003 NSF-Program Participant Survey," National Science Foundation, Arlington, VA: SRI International February 2004.

4 S. Russell, "Evaluation of NSF Support for Undergraduate Research Opportunities: 2003 NSF Program Participant Survey," February 20042004. 
E. T. Pascarella and P.T. Terenzini, How College Affects Students, Volume 2. San Francisco: Jossey-Bass, 2005.

$6 \quad$ M. Reichert and M. Absher, "Graduate Engineering Education of Underrepresented Populations," Journal of Engineering Education, vol. 87, pp. 257-267.

$7 \quad$ M. Anderson-Rowland and P. Johnson, "Encouraging Underrepresented Minority and Women Students to Become Interested in Research and to Attain Graduate Degrees," presented at Proceedings of the 2004 American Society for Engineering Education Annual Conference \& Exposition, 2004.

$8 \quad$ G. May, "A SUPERB Experience," National Society of Black Engineers Magazine, 1991.

$9 \quad$ E. Barnes, "Getting Minorities into Ph.D. Pipeline Requires Active and Early Intervention, Say Experts," Black Issues in Higher Education, 1992.

10 D. Dillman, Mail and Internet Surveys: The Tailored Design Method: John Wiley \& Sons, 2000.

11 G. D. Garson, "Logistic Regression," http://www2.chass.ncsu.edu/garson/PA765/logistic.htm, 2006, Lasted Accessed on January 16, 2007. 